\title{
The possible impact of uveitis in blindness: a literature survey
}

\author{
M S A Suttorp-Schulten, A Rothova
}

The inflammatory process of the uvea is called uveitis and may cause sight threatening damage to the eye. The aetiological factor in about $30 \%$ of the cases of uveitis is unknown. If established clinical entities without known cause, such as Fuchs' uveitis, are included, no aetiological agent or association with systemic disease can be identified in about $50 \%$ of cases. ${ }^{1}$ Uveitis may be induced by infection, autoimmune disease, trauma, or malignancy. It is recommended that the different forms of uveitis should be classified according to their anatomical localisationanterior uveitis, intermediate uveitis, posterior uveitis, and panuveitis. $^{23}$

The uvea plays an important role in the ocular immunological defence mechanisms. Immunologically speaking the eye has a deviant and privileged position because of the blood-retina barrier, absence of lymphatic drainage, and a special feature called the anterior chamber associated immune deviation (ACAID). These special defence mechanisms contribute to the preservation of vision. ${ }^{4}$ If these defence mechanisms fail, intraocular inflammation will arise. Uveitis, mainly posterior uveitis, is an important cause of blindness, resulting in $10 \%$ of all cases of blindness. ${ }^{56}$

Although uveitis is a well known cause of blindness, there is only scant knowledge concerning the prevalence and incidence of uveitis among the blind. In most epidemiological studies dealing with blindness, uveitis was not considered a distinct entity. ${ }^{7-13}$ The complications of uveitis-for example, cataract, secondary glaucoma, and macular abnormalities, are included in many epidemiological studies about blindness, but how many of these are actually attributable to uveitis is not specified. ${ }^{7}$ The largest population based study of the Western world, the Framingham Eye Study, illustrates this phenomenon: patients with blindness due to retinal toxoplasma lesions are classified as having macular degeneration; secondary cataract is indicated but carries no aetiological diagnosisfor example, uveitis, trauma. ${ }^{7}$ Proper population based studies on the extent of uveitis as a cause of blindness and visual impairment unfortunately do not exist, although such data would be a very beneficial contribution to our knowledge about uveitis.

\section{Definitions}

Blindness and low vision are always measured as the visual acuity of the better eye, since vision in this eye determines the actual maximum binocular visual acuity. Blindness is defined by the World Health Organisation (WHO) as the best possible corrected visual acuity in the better eye of less than $0.05(20 / 400)$ or corresponding visual field loss of $\leq 10^{\circ}$. Severe visual impairment is defined as the best possible corrected visual acuity in the better eye of $0.05(20 / 400)$ or more but less than $0.1(20 / 200)$ (see Table 1)..$^{81415}$

Legal blindness is defined as the level of blindness that makes a person eligible for a reduction in tax and other

benefits in certain countries. In the USA and in most Anglo-American countries the threshold for this is 0.1 (20/ 200 ) or worse or a visual field $\leq 20^{\circ}$. Moderate visual impairment which makes the person eligible for educational assistance in the USA is defined as a visual acuity of 0.25 to $0.12(20 / 70$ to $20 / 160)$. For the purpose of this survey blindness was defined as visual acuity in the better eye of less than $0.05(20 / 400)$ and visual impairment as $0.05(20 / 400)$ or better but less than $0.1(20 / 200)$.

Worldwide blindness is defined as all the blind people in the world. The Western world is defined as the established market economies-Western Europe and North America.

Prevalence is the number of cases, new and old, within a population with a certain disease existing at a given time and is usually expressed as a percentage. Exact prevalence numbers can only be obtained from population based studies. Incidence is the number of new cases of a condition that occur within a specified period of time and is usually expressed as a percentage or per 1000 of the population at risk. ${ }^{16}$

\section{Causes of blindness worldwide}

It was estimated in 1995 that 38 million people in the world are blind, $0.7 \%$ of the total population, while an additional 110 million people worldwide have visual impairment. By far the majority $(75 \%)$ of worldwide blindness occurs in Africa and Asia, with the highest prevalence in sub-Saharan Africa where $1.4 \%$ of the total population is blind compared with, for instance, $0.3 \%$ in the Western world. ${ }^{8}$ Cataract is the leading cause of worldwide blindness followed by trachoma and glaucoma, accounting together for $71 \%$ of all blindness. If these figures are divided and analysed by economic region considerable differences are found. All treatable causes of blindness-for example, cataract and glaucoma, have a much lower frequency in the Western world; here, for example, cataract accounts for $3.5 \%$ of blindness, while this percentage is $57.6 \%$ in Latin America and the Caribbean. $^{8}$ Naturally, these differences are explained by advanced surgical techniques and easier access to medical care.

The results of these studies on blindness in the Western world are difficult to interpret. Very often the classification of diseases is not consistent: anatomical diagnosis (for example, corneal opacities, cataract) and causal diagnosis (for example, onchocerciasis, trachoma) are used in one and the same system simultaneously. Thus, in most studies one entity may appear in different categories-for exam-

Table 1 Blindness defined as visual acuity in the better eye (adapted from Thylefors et al, ${ }^{8}$ Thylefors, ${ }^{14}$ and Simons ${ }^{15}$ )

Blindness WHO

Severe visual impairment WHO

Legal blindness
$<20 / 400(0.05)$

$>20 / 400$ and $<20 / 200$

$\geq 0.05$ and $<0$.

$\leq 20 / 200(0.1)$

Visual field $\leq 20^{\circ}$ 
ple, uveitis and its various complications. Unfortunately, simultaneous classification using anatomical and causal diagnosis was recommended by the WHO. ${ }^{14}$ Therefore the comparison of results is often not possible.

Several studies have been conducted among the elderly and are either not representative population based sample surveys, or are based on hospital populations or government registered institutions for the blind, which have been shown to underestimate the number of blind people and specific causes of blindness. ${ }^{9} 10^{1317}$ Prevalence statistics on the causes of blindness are actually available only from developing countries. ${ }^{16}$ The exact percentage of worldwide blindness due to uveitis and the impact of uveitis on worldwide blindness is unknown, owing to the problems in epidemiological statistics mentioned above.

\section{Blindness in the Western world}

In the Western world, blindness is mainly the result of disorders of the posterior segment of the eye as age-related macular degeneration and diabetic retinopathy. Both are associated with older age and account for $12 \%$ to $43 \%$ and $7 \%$ to $17 \%$ of all cases of blindness. ${ }^{11-131819}$ As visual impairment due to diabetic retinopathy has become treatable because of increased screening and early treatment, its incidence has decreased relatively compared with agerelated macular degeneration where, essentially, no treatment is available. ${ }^{112}$

There are some differences reported about the prevalence of causes of blindness between the European countries and the USA. ${ }^{20}$ As study designs are often different, the comparison of data is extremely difficult. Of special interest is the higher incidence of blindness among the black population in the USA, probably mainly the result of socioeconomic factors and the high incidence of glaucoma in this population group. ${ }^{21-23}$ Recently, it has been reported that the prevalence of age-related macular degeneration may be less common in Europe than the USA. ${ }^{24}$ It has been estimated that uveitis causes $10 \%$ of the cases of blindness in the USA, while European studies mention percentages of $3 \%$ to $7 \%$. $^{5181925}$

\section{Blindness in the developing countries}

Many cases of blindness in the developing countries would essentially be treatable or preventable if the resources and staff were available. Much attention has been paid in ophthalmological discussions to cataracts in developing countries. ${ }^{26}{ }^{27}$ But, in addition to surgical problems such as cataracts, one must not forget that many other ocular diseases in developing countries may be prevented (see Table 2). ${ }^{28}{ }^{29}$ Prevention of these diseases is obviously a major problem, as they still have a high prevalence in developing countries. For example, the leading cause of world childhood blindness is vitamin A deficiency causing xerophthalmia, which accounts for $70 \%$ of 500000 blind children every year. ${ }^{8}$ Infectious causes of keratitis and uveitis may be treatable and form a major problem in this part of the world. Trachoma alone accounts for one quarter of all the blind people in the world. This is also the case in onchocerciasis which ranks as the fourth cause of blindness worldwide and is mainly seen in sub-Saharan Africa. ${ }^{8}$ Visual loss in onchocerciasis is the consequence of inflammation of both the anterior and posterior segment. Prevention may be possible by the annual administration of ivermectin, and fortunately the number of infected patients is decreasing. ${ }^{28}{ }^{30}{ }^{31}$ Nevertheless, the number of blind people as a result of onchocerciasis (globally 360000 ), one of the uveitis entities, indicates the tremendous portion of blindness caused by intraocular inflammation. ${ }^{8}$ An estimated 250000 people in the world are blind because of the sequelae of leprosy, another infectious
Table 2 Major causes of blindness in the developing countries (adapted from Thylefors et $a^{8}$ )

\begin{tabular}{ll}
\hline 1 Cataract & \\
2 Trachoma $^{\star}$ & 14000000 \\
3 Glaucoma $^{\star}$ & 5866000 \\
4 Onchocerciasis $^{\star}$ & 4800000 \\
\hline
\end{tabular}

^Possibly treatable (that is, preventable).

disease. ${ }^{32}{ }^{33}$ To illustrate the magnitude of this number the estimated number of world blindness due to diabetic retinopathy is also $250000 .^{32}$

How many of the cases of cataracts, glaucomas, retinal and optic atrophies in the developing countries are secondary to uveitis is not precisely known. Several studies mention percentages of blindness due to uveitis as between 2.4 and $10 \%$, excluding onchocerciasis. ${ }^{34-41}$ In a recent study in west Africa, uveitis, including onchocerciasis, ranked as second cause of blindness accounting for $24 \%$. Non-onchocercal uveitis still ranked as the second cause with $10 \%{ }^{39}$ Considering that onchocerciasis is ranked as the fourth single cause of blindness, one may extrapolate that if other infectious and inflammatory causes such as, for example, leprosy are added, uveitis may rank even higher than fourth in the developing world.

\section{Blindness and age in the Western world}

Most of worldwide blindness occurs in the elderly; $58 \%$ are estimated to be older than 60 years and $3.8 \%$ of blindness occurs in people younger than 14 years. ${ }^{8}$ In the Western world, all frequent causes of blindness are associated with increasing age (see Table 3). The blindness rate in 90-yearolds is twice that observed in 60-year-olds. ${ }^{13}{ }^{20}$ Age-related macular degeneration is the leading cause of new cases of blindness in the USA, where it affects $8 \%$ to $20 \%$ of the people over the age of 65 and accounts for between a quarter and a half the cases of blindness. ${ }^{72} 132021244243$ Cataract is still a major cause of worldwide blindness, accounting for $13 \%$ to $27 \%$ of all blind people, strongly increasing with age. Blindness from glaucoma is possibly preventable and is found to be the cause of $10 \%$ to $12 \%$ of blindness in the elderly. ${ }^{11-13}$ Although the prevalence of diabetic retinopathy in this age group increases with age, this disease ranks as the fourth cause of blindness at $2 \%$ to $7 \%$ (see Table 3). ${ }^{71-13}$

Blindness in children in the Western world is mostly seen in conditions that lead to blindness in very early childhood and about half of children are blind as a result of brain disorders. The major ocular causes are retinopathy of prematurity $(20 \%)$, optic nerve atrophy (20\%), congenital malformations, $(15 \%)$ and tapetoretinal degenerations (10\%) (see Table 4). ${ }^{44-47}$ The incidence of several of these is decreasing as a result of prevention, early treatment, and prenatal diagnosis. ${ }^{47}$ Studies on the registration of blind people in a hospital population or blind registration studies have shown that the middle aged group represents about $26 \%$ to $32 \%$ of all the blind people in a Western population..$^{121921}$ Only a limited number of studies report data on specific age groups other than the elderly or children. Reported diseases that cause blindness at a younger age than 65 years included accidents, optic nerve atrophy, tapetoretinal degeneration, congenital anomalies, and toxic damage including retinopathy of prematurity and

Table 3 Major causes of blindness of the elderly in the Western world (adapted from Leibowitz et al, ${ }^{7}$ Aclimandos et al, ${ }^{11}$ and Tielsch et al ${ }^{13}$ )

\begin{tabular}{ll}
\hline Age-related macular degeneration & $40 \%$ \\
2 Cataract & $20 \%$ \\
3 Glaucoma & $11 \%$ \\
4 Diabetic retinopathy & $5 \%$
\end{tabular}

^Possibly treatable (that is, preventable). 
Table 4 Major causes of blindness in children in the Western world (adapted from Schmidt et al, ${ }^{44}$ Drews et al, ${ }^{45}$ and Goggin and O'Keefe ${ }^{46}$ )

\begin{tabular}{ll}
\hline 1 Retinopathy of prematurity & $20 \%$ \\
2 Optic nerve atrophy & $20 \%$ \\
3 Congenital malformations & $15 \%$ \\
4 Tapetoretinal degeneration & $10 \%$ \\
\hline
\end{tabular}

$\star$ Possibly treatable (that is, preventable).

Table 5 Major causes of blindness in the middle age group in the Western world (adapted from Nussenblatt, ${ }^{5}$ Thompson et al, ${ }^{12}$ Krumpaszky and Klauss, ${ }^{19}$ and Makabe et al ${ }^{25}$ )

1 Tapetoretinal degeneration

2 Congenital anomalies (including high myopia)

3 Diabetes *

4 Accidents ${ }^{\star}$

5 Uveitis*

\section{$20 \%$}

$20 \%$

$20 \%$

$5 \%$

$10 \%$

^Possibly treatable (that is, preventable)

diabetes. The mean blinding age is 65 for diabetic retinopathy and 73 for glaucoma. ${ }^{25}$ The prevalence data reported are variable, but give more or less consistent figures about tapetoretinal degeneration and diabetic retinopathy in middle age with up to $20 \%$ and $20 \%$ respectively (see Table 5)..$^{121925}$

Economically speaking, the middle aged group (aged 20 to 65 years) is the most important as it includes the working age range. For many causes of blindness in this group no definitive cure is available. As Table 5 indicates, the blindness in adults in middle age that is caused by treatable diseases narrows down essentially to two large entities: diabetic retinopathy and uveitis accounting for about $20 \%$ and $10 \%$ respectively. ${ }^{512}$ The main cause of blindness in diabetes is not proliferative retinopathy any more but macular oedema occurring in exudative diabetic retinopathy ${ }^{48-50}$ Thus, blindness due to diabetes will probably decrease in the younger age group, while it is expected to increase despite treatment in the older age group because of a proportionally larger increase of patients living longer with diabetes mellitus and a higher incidence of macular oedema. ${ }^{51}{ }^{52}$ As mentioned earlier, only a few studies describe the causes of blindness in the middle aged adult. This is astonishing as it has been reported that $97 \%$ of the annual federal budgetary costs of blindness in the USA is spent on blind people in the adult group of working age. ${ }^{53}$

\section{Uveitis as a cause of blindness in the Western world}

The sequelae of uveitis that may cause visual impairment are well known and include cataract, glaucoma, band keratopathy, vitreous opacities, retinal scars, retinal detachment, retinal vascular abnormalities, cystoid macular oedema, and optic atrophy. Several of these are surgically treatable, such as cataract and glaucoma. ${ }^{54}$ There are no studies on the incidence of these vision threatening complications in uveitis, so the impact of therapy and prevention of visual loss in uveitis still remains unclear.

Blindness due to uveitis is usually not reflected in results reported on epidemiology of blindness and only few data are available about its incidence. It is estimated that it causes $10 \%$ to $15 \%$ of all cases of total blindness in the USA. ${ }^{56}$ The percentage of blindness in the Western world that was attributed to uveitis was similar in those studies where uveitis was reported, and varied from $3 \%$ to $7 \%$ of the total blindness. As these studies do not include all uveitis cases and do not report separately on the complications of uveitis, such as cataract and glaucoma, this percentage is probably higher. ${ }^{18} 1925$

The prevalence of uveitis in Western countries has been reported as 38 per 100000 and the incidence is about 14 to 17 per 100000 of the population. ${ }^{55-59}$ Several reports on the frequency of the different types of uveitis use the classification of the international uveitis study group and show similar proportions of anatomical entities. ${ }^{35660}$ Most uveitis patients present at an age when they are in the most active period of their working life; approximately 70-90\% are between 20 and 60 years old. In about half the patients the age of onset is in the third or fourth decade of life. ${ }^{26566061-63}$ This age distribution makes uveitis one of the ocular diseases with an important socioeconomic impact.

No major difference in the causes of uveitis could be found when comparing a British with an American population. This study did not include any patients with presumed ocular histoplasmosis, a disease mainly seen in the USA. ${ }^{64}$ Naturally, there are demographic and genetic factors influencing the frequency of several diseases (for example, Behçet's disease and Vogt-Koyanagi-Harada syndrome). ${ }^{576165}$ In studies that describe the changes of frequency of potentially blinding diseases in past decades, the relative part played by uveitis is still essentially the same. ${ }^{182544}$ None of these studies as yet included patients with more recent uveitis entities such as cytomegalovirus retinitis and acute retinal necrosis, two entities with a poor prognosis that will influence the number of blind cases due to uveitis.

Uveitis patients often do not suffer from ocular disease alone; approximately $25 \%$ to $50 \%$ have an underlying systemic disease. ${ }^{260}$ It is not known exactly how many of the uveitis patients suffer from blindness or visual impairment; one study mentions a loss of $25 \%$ visual acuity in $4 \%$ of patients with anterior uveitis, $43 \%$ with posterior uveitis, and $40 \%$ with panuveitis. ${ }^{66}$ Another recent study reports on $35 \%$ visual impairment or blindness, mainly due to posterior uveitis, with cystoid macular oedema as a leading cause. $^{67}$

Many data are available on the prognosis of visual acuity of specific aetiology. Acute anterior uveitis, accounting for at least $30 \%$ of all uveitis cases, has a good prognosis and leads to visual impairment in only $1 \%$ of the patients, whether it is associated with HLA B 27 or not. ${ }^{68}$ Toxoplasmosis is the aetiological factor in about $10 \%$ of all uveitis patients and occurs mainly in young adults; it leads to severe visual impairment or blindness as a result of the central localisation of the lesion in at least $9 \%$ of the eyes affected. ${ }^{69}{ }^{70}$ Ocular sarcoidosis accounts for up to $9 \%$ of all uveitis patients and causes blindness in at least one eye in $10 \% .{ }^{71}$ Several forms of posterior uveitis and panuveitis are rare in the Western world but have a poor visual prognosis-for example, Behçet's disease, acute retinal necrosis, serpiginous chorioretinopathy, and cytomegalovirus retinitis. ${ }^{72-75}$

Of special interest is blindness in patients with acquired immunodeficiency syndrome (AIDS), which is still increasing and is almost always due to viral uveitis. Cytomegalovirus retinitis will develop in $20 \%$ to $34 \%$ of patients with AIDS. Untreated, it will lead to blindness within several months. ${ }^{75}$ Owing to failure of virostatic treatment to control the disease, the retinitis recurs in the majority of patients. As improved therapy leads to longer survival in AIDS patients, it can be expected that the number of blind AIDS patients will increase. ${ }^{76}$

\section{Socioeconomic impact of blindness due to uveitis} In the USA the estimated federal budget costs for a blind person in the working age group-excluding costs for medical care, but including all state benefits, etc, amount to $\$ 12000$ per person year. ${ }^{53}$ It is reported that in the USA alone 1.1 million are legally blind, 337000 of them in the age group between 20 and 65 years. It is estimated that in the USA alone 2.3 million suffer from uveitis and that uveitis causes $10 \%$ of the blindness encountered. ${ }^{77}{ }^{78}$ If one 
assumes that the value of $6 \%$ of the epidemiological studies is the baseline for middle aged people blinded by uveitis-which is probably an underestimate-this amounts to 20220 blind people with a total of annual costs for this group of about $\$ 242.6$ million in the USA alone. A similar calculation for diabetic patients in this age group adds up to 242.7 million in the USA. ${ }^{53}$ Taking into account the facts that many uveitis entities are curable and that its damage may be prevented or limited if treated early and adequately, further investment-whether financial, medical, or research - can be said to be valuable for the patient as well as the budget of the community.

We thank Dr A Kijlstra for reviewing the manuscript.

\section{S A SUTTORP-SCHULTEN}

Netherlands Ophthalmic Research Institute,

Amsterdam, The Netherlands

A ROTHOVA

Netherlands Ophthalmic Research Institute,

Amsterdam, The Netherlands

and the F C Donders Institute for Ophthalmology,

Academic Hospital Utrecht,

The Netherlands

1 Rothova A, Buitenhuis HJ, Meenken C, Brinkman CJ, Linssen A, Alberts C, et al. Uveitis and systemic disease. Br f Ophthalmol 1992;76:137-41.

2 Barsky D. Anatomy of the uveal tract. In: Tasman W, Jaeger EA, eds. Duane's clinical ophthalmology. Vol 4. Philadelphia: J B Lippincott, 1990: chapter 31, $1-10$.

3 Bloch-Michel E, Nussenblatt RB. International Uveitis Study Group recommendation for the evaluation of intraocular inflammatory disease. Am f Ophthalmol 1987;103:234-5.

4 Streilein JW. Immunopathologic consequences of ocular immune privilege. In: Bialasiewicz AA, Schaal KP, eds. Infections and diseases of the eye. Buren, In: Bialasiewicz AA, Schaal KP, eds. Infectid
Netherlands: Aeolus Press, 1994:53-64.

5 Nussenblatt RB. The natural course of uveitis. Int Ophthalmol 1990;141: 303-8.

6 Darrel RW, Wagener HP, Kurland LT. Epidemiology of uveitis. Arch Ophthalmol 1962;68:502-14.

7 Leibowitz HM, Krueger DE, Maunder LR, Milton RC, Kini MM, Kahn HA, et al. The Framingham Eye Study Monograph. Surv Ophthalmol (suppl) 1980;24:335-610.

8 Thylefors B, Negrel AD, Pararajasegaram R, Dadzie KY. Global data on blindness. WHO Bulletin 1995;73:115-121.

9 Robinson R, Deutsch J, Jones HS, Youngson-Reilly S, Hamlin DM, Dhurjon $\mathrm{L}$, et al. Unrecognised and unregistered visual impairment. $\mathrm{Br} \mathcal{F}$ Ophthalmol 1994;78:736-40.

10 Wormald RPL, Wright LA, Courtney P, Beaumont B, Haines AP. Visual problems in the elderly population and implications for services. $B M \mathcal{F}$ 1992;304:1226-9.

11 Aclimandos WA, Galloway NR. Blindness in the City of Nottingham (1980-1985). Eye 1988;2:431-4.

12 Thompson JR, Du L, Rosenthal AR. Recent trends in the registration of blindness and partial sight in Leicestershire. Br $\mathcal{F}$ Ophthalmol 1989;73:959.

13 Tielsch JM, Javitt JC, Coleman A, Katz J, Sommer A. The prevalence of blindness and visual impairment among nursing home residents in Baltimore. N Engl $\mathcal{F}$ Med 1995;332:1205-9.

14 Thylefors B. A simplified methodology for the assessment of blindness and its main causes. Whd Hlth Statist Quart 1987;40:129-41.

15 Simons $K$. Visual acuity and the functional definition of blindness. In: Tasman W, Jaeger EA, eds. Duane's clinical ophthalmology. Philadelphia: Tasman W, Jaeger EA, eds. Duane's clinical ophth

16 Johnson GJ, Minassian DC. Prevalence of blindness and eye disease: discussion paper. $\mathcal{F}$ Roy Soc Med 1989;82:351-4.

17 Wormald R, Evans J. Registration of blind and partially sighted people. [Editorial] Br f Ophthalmol 1994;78:733-4.

18 ten Doesschate J. Causes of blindness in the Netherlands. Doc Ophthalmol 1982;52:279-85.

19 Krumpaszky HG, Klauss V. Erblindungsursachen in Bayern. [Cause of blindness in Bavaria] Klin Monatsbl Augenheilkd 1992;200:142-6.

20 Hyman L. Epidemiology of eye disease in the elderly. Eye 1987;1:330-41.

21 Tielsch JM, Sommer A, Witt K, Katz J, Royall R. Blindness and visual impairment in an American urban population. Arch Ophthalmol 1990;108: 286-90.

22 Javitt JC. Preventing blindness in Americans: the need for eye health education. Surv Ophthalmol 1995;40:41-4.

23 Javitt JC. Universal coverage and preventable blindness. Arch Ophthalmol 1994;112:453.

24 Vingerling JR, Dielemans I, Hofman A, Grobbee DE, Hijmering M, Kramer $\mathrm{CF}$, et al. The prevalence of age-related maculopathy in the Rotterdam Eye study. Ophthalmology 1995;102:205-10.

25 Makabe R, Hellwig A. Wandel der Erblindungsursachen in jungster Zeit. Versicherungsmedizin 1988;5:136-9.

26 Foster A. Who will operate on Africa's 3 million curably blind people? Lancet 1991;337:1267-9.

27 Potter AR. Preventing blindness worldwide. BMF 1994;309:682-3.

28 Kupfer C, Underwood B, Gillen T. Leading causes of visual impairment worldwide. In: Albert DM, Jakobiec FA, eds. Principles and practice of ophthalmology. Philadelphia: WB Saunders, 1994:vol 1,1249-55.

29 Foster A, Johnson G. Blindness in the developing world. Br $\mathcal{F}$ Ophthalmol 1991;77:398-9.
30 Rothova A, vd Lelij A, Stilma JS, Wilson WR, Barbe RF. Side-effects of ivermectin treatment of onchocerciasis. Lancet 1989;338:1439-41.

31 Rothova A, vd Lelij A, Stilma JS, Klassen-Broekema N, Wilson WR, Barbe RF. Ocular involvement in patients with onchocerciasis after repeated treatment with ivermectin. Am $\mathcal{f}$ Ophthalmol 1990;110:6-16.

32 Foster A, Johnson GJ. Magnitude and causes of blindness in the developing world. Int Ophthalmol 1990;14:135-40.

33 Waddell KM, Saunderson PR. Is leprosy blinding? $\mathrm{Br} f$ Ophthalmol 1995;79:250-6.

34 Abiose A, Murdoch I, Babalola O, Cousens S, Liman I, Onyema J, et al. Distribution and aetiology of blindness and visual impairment in mesoendemic onchocercal communities, Kaduna State, Nigeria. $\mathrm{Br} \mathcal{f}$ Ophthalmol 1994;78:8-13.

35 Olurin $O$. Etiology of blindness in Nigerian children. Am $\mathcal{f}$ Ophthalmol 1970;70:533-40.

36 Potter AR. Causes of blindness and visual handicap in the Central African Republic. Brf Ophthalmol 1991;75:326-8.

37 Quana'a P, Alemu B, Alemaychu W. Causes of blindness observed in the eye department of an Addis Ababa hospital. Ethiop Med $\mathcal{F} 1986 ; 24: 19-23$.

38 Rapoza PA, West SK, Katala SJ, Taylor HR. Prevalence and causes of vision loss in central Tanzania. Int Ophthalmol 1991;15:123-9.

39 Ronday MJH, Stilma JS, Barbe RF, Kijlstra A, Rothova A. Blindness from uveitis in a hospital population in Sierra Leone. Br f Ophthalmol 1994;78: 690-3.

40 Stilma JS, Bridger S. Causes and prevalence of blindness in the northern province of Sierra Leone. Doc Ophthalmol 1983:115-22.

41 Whitworth JAG, Gilbert CE, Mabey DM, Morgan D, Foster A. Visual loss in an onchocerciasis endemic community in Sierra Leone. $\mathrm{Br} F$ Ophthalmol 1993;77:30-2.

42 Bressler NM, Bressler SB, West SK, Fine SL, Taylor HR. The grading and prevalence of macular degeneration in Chesapeake Bay watermen. Arch Ophthalmol 1989;107:847-52.

43 Klein R, Klein BEK, Linton KLP. Prevalence of age-related maculopathy. The Beaver Dam Eye Study. Ophthalmology 1992;99:933-43.

44 Schmidt U, Murken J, Klauss V. Wandel der Blindheitsursachen im Kindesalter. Klin Monatsbl Augenheilkd 1988;193:457-64.

45 Drews $C D$, Yeargin-Allsop M, Murphy CC, Decouffle P. Legal blindness among 10-year-old children in Metropolitan Atlanta: prevalence, 1985 to 1987. Am $\mathcal{F}$ Publ Health 1992;82:1377-9.

46 Goggin M, O'Keefe M. Childhood blindness in the Republic of Ireland: a national survey. Br f Ophthalmol 1991;75:425-9.

47 Rosenberg T, Flage T, Hansen E, Riise R, Rudanko SL, Viggosson G, et al. Incidence of registered visual impairment in the Nordic children. $\mathrm{Br} \mathcal{F}$ Ophthalmol 1996;80: 49-53.

48 Early Treatment Diabetic Retinopathy Study Research Group. Early photocoagulation for diabetic retinopathy. Ophthalmology 1991;98:766-85.

49 Lee CM, Olk RJ. Modified grid laser photocoagulation for diffuse diabetic macular edema. Ophthalmology 1991;98:1594-602.

50 Diabetes Control and Complications Trial Research Group. The effect of intensive treatment of diabetes on the development and progression of long term complications in insulin dependent diabetes mellitus. $N$ Engl f Med 19rm complications

51 Fong DS, Rand LI. Epidemiology of diabetic retinopathy. In: Albert DM, Jakobiec FA, eds. Principles and practice of ophthalmology. Philadelphia: WB Saunders, 1994, vol 1, 1285-96.

52 Moss SE, Klein R, Klein BEK. Ten-year incidence of visual loss in a diabetic population. Ophthalmology 1994;101:1061-70.

53 Chiang Y, Bassi LJ, Javitt JC. Federal budgetary costs of blindness. The Milbank Quarterly 1992;70:319-40.

54 Nussenblatt RB, Palestine AG. Clinical evaluation of the uveitis patient. In Nussenblatt RB, Palestine AG, eds. Uveitis, fundamentals and clinical practice. Chicago: Year Book, 1989:53-102.

55 Vadot E, Barth E, Billet P. Epidemiology of uveitis-preliminary results of a prospective study in Savoy. In: Saari KM, ed. Uveitis update. Amsterdam: Elsevier, 1984:13-6.

56 Tran VT, Auer C, Guex-Crosier, Pittet N, Herbort CP. Epidemiology of uveitis in Switzerland. Ocular Immunology and Inflammation 1994;2: 169-76.

57 Baarsma GS. The epidemiology and genetics of endogenous uveitis: a review. Curr Eye Res (suppl) 1992;11:1-9.

58 Miettinen R. Incidence of uveitis in northern Finland. Acta Ophthalmol 1977;55:252-60.

59 Mortensen KK, Sjolie AK, Goldschmidt E. Uveitis, eine epidemiologische Untersuchung. Ber Dtsch Ophthalmol Ges 1981;78:97-101.

60 Smit RLMJ, Baarsma S, de Vries J. Classification of 750 consecutive uveitis patients in the Rotterdam Eye Hospital. Int Ophthalmol 1993;17: 71-75.

61 Chavis PS, Wafai MZ, Al-Amra S, Tabbara KF. Uveitis in the Middle East. In: Dernouchamps JP, Verougstraete C, Caspers-Velu L, Tassignon MJ, eds. Recent advances in uveitis. Amsterdam, New York: Kugler Publications, 1993:149-56.

62 Knox DL. Epidemiology of uveitis. Trans Ophthalmol Soc UK 1981;101:294

63 Vassileva P, Dimova P1, Parvova T, Parvanov. Prevalence of uveitis in the Sofia district. In: Dernouchamps JP, Verougstraete C, Caspers-Velu L, Tassignon MJ, eds. Recent advances in uveitis. Amsterdam, New York: Kugler Publications, 1993:1458.

64 Perkins ES, Folk J. Uveitis in London and Iowa. Ophthalmologica 1984;189: 36-40

65 Sugita M, Enomoto Y, Nakaura S, Ohba S, Yamamoto T, Ohno S. Epidemiological study on endogenous uveitis in Japan. In: Dernouchamps JP, Verougstraete C, Caspers-Velu L, Tassignon MJ, eds. Recent advances in uveitis. Amsterdam, New York: Kugler Publications, 1993:161-3.

66 Couto C, Merlo JL. Epidemiological study of patients with uveitis in Buenos Aires, Argentina. In: Dernouchamps JP, Verougstraete C, Caspers-Velu L, Tassignon MJ, eds. Recent advances in uveitis. Amsterdam, New York: Kugler Publications, 1993:171-4.

67 Rothova A, Suttorp-Schulten MSA, Treffers WF, Kijlstra A. Causes and frequency of blindness in patients with intraocular inflammatory disease. Brf Ophthalmol 1996;80:332-6.

68 Linssen A, Meenken C. Outcomes of HLA-B-27 positive and HLA-B27negative acute anterior uveitis. Am f Ophthalmol 1995;120:351-61.

69 Rothova A. Ocular involvement in toxoplasmosis. Br f Ophthalmol 1993;77: 371-7. 
70 Rothova A, Meenken C, Buitenhuis HJ, Brinkman CJ, Baarsma GS, BoenTan TN, et al. Therapy for ocular toxoplasmosis. Am $\mathcal{f}$ Ophthalmo 1993;115:517-23.

71 Rothova A, Alberts C, Glasius E, Kijlstra A, Buitenhuis HJ, Breebaart. Risk factors for ocular sarcoidosis. Doc Ophthalmol 1989;72:287-96.

72 Towler HMA, Lightman S. Visual prognosis in Behçet's disease. Ocul Immunol Inflamm 1993;1:249-54.

73 de Boer JH, Luyendijk L, Rothova A, Baarsma GS, De Jong PTVM, Bollemeijer JG. Detection of intraocular antibody production to herpes meijer JG. Detection of intraocular antibody production to herpes
viruses in acute retinal necrosis syndrome. Am $f$ Ophthalmol 1994;117:20 $1-10$.
74 Weiss H, Annesley WH Jr, Shields JA, Tomer T, Christopherson K. The clinical course of serpiginous choroidopathy. Am $\mathcal{F}$ Ophthalmol 1979;87: $133-42$.

75 Holland GN. Ophthalmic diseases associated with human immunodeficiency virus infections. In: Bialasiewicz AA, Schaal $\mathrm{KP}$, eds. Infections and diseases of the eye. Buren, Netherlands: Aeolus Press, 1994: 524-34.

76 Roarty JD, Fisher EJ, Nussbaum JJ. Long term visual morbidity of cytomegalovirus retinitis in patients with acquired immune deficiency syndrome. Ophthalmology 1993;100:1685-8.

77 Annual report 1993. New York: Research to prevent blindness, 1993:4.

78 Annual report 1994. New York:Research to prevent blindness, 1994:1-4. 